Hanna JAXA-RoŻEN

Uniwersytet Wrocławski

\title{
Podmiot feministyczny w koncepcjach Luce Irigaray, Julii Kristevy oraz Donny Haraway
}

\section{Podmiot feministyczny}

Drzedmiotem postmodernistycznej debaty jest koncepcja świata i człoPieka w filozofii określanej jako oświeceniowa, modernistyczna lub nowożytna, której punktem kulminacyjnym jest kantowsko-kartezjański paradygmat wiedzy. Wzmagające się w drugiej połowie naszego wieku przekonanie, iż bagaż intelektualny pozostawiony przez Oświecenie domaga się symbolicznej i politycznej rewolucji otworzyło dyskusję, która ogarnęła wszystkie dziedziny humanistyki. Feministyczna teoria emancypacji nie mogła pozostać obojętna na przemiany, znajdujące odzwierciedlenie na wszystkich obszarach kulturowej rzeczywistości. Wiara w monolityczny podmiot, wolny od ograniczeń w obliczu wydarzeń, które przez ostatnie wieki przyniosło życie, rozpadła się, pozostawiając jedynie melancholię wykorzenienia.

Do dyskusji o kształcie nowej podmiotowości włączył się więc również feminizm, zwłaszcza feminizm drugiej fali. Jest on nie tylko dyskursem, który proponuje inne spojrzenie na człowieka, ale także refleksja, która ukazuje wszystkie trudności, jakie wiążą się z mówieniem o podmiocie.

Feministyczny kontrapunkt do postmodernistycznego tematu śmierci człowieka jako podmiotu może być nazwany demistyfikacją męskiego podmiotu racjonalnego. Podmiot w zachodniej tradycji intelektualnej był zazwyczaj - choć tego nie artykułowano wprost - białym, władca, chrześcijaninem, mężczyzną, głową domu. Współcześnie zmieniło się to o tyle, że postmoderniści zastępują człowieka, suwerenny wyżej opisany podmiot, teoretycznymi i praktycznymi założeniami tradycji, studium przypadku, historycznie zmiennymi i kulturalnie zróżnicowanymi społecznie językowymi i dyskursywnymi praktykami. Feministki wskazują natomiast, że płeć i różne praktyki przyczyniające się do jej ukonstytuowania, są jednym z najbardziej kruchych kontekstów, w których powinien być 
konstytuowany naturalny i uniwersalny podmiot. Poszukująca go zachodnia tradycja filozoficzna usiłowała więc odnaleźć głębokie struktury doświadczenia i świadomości, które, jak twierdziła, byłyby reprezentatywne dla człowieka jako takiego, przede wszystkim zaś - ratowały go przed grozą wykorzenienia, przypadkowością losu, przygodnością cielesnego bytu. Choć w historii filozofii znaleźć można wielu, którzy obwieszczali dosięgnięcie wymarzonego „czystego opisu” ludzkiej kondycji, jednak niezmiennie okazywało się, że nie jest to opis pełny. Rozmaite były te mankamenty, jednak jeden był dla wszystkich proponowanych teorii wspólny: pomijana była różnica płci jako wyraz i struktura doświadczenia. W większości koncepcji ważną, ograniczającą rolę odgrywało odrzucenie wszelkiego subiektywizmu, tak dla kobiecego myślenia istotnego; na nim zostanie ufundowana feministyczna koncepcja podmiotowości w ogóle, w tym kobiecej w szczególności.

Filozofia zachodnia generalnie przedstawia się jako dyskurs niezróżnicowanych podmiotów, ograniczający naszą zdolność widzenia i odbierający rację bytu temu, co inne i różne, nie pasujące do ustanowionej kategorii podmiotu. Od Platona przez Kartezjusza po Kanta i Hegla filozofia stanowi historię podmiotu męskiego, racjonalnego i racjonalizującego.

\title{
Luce Irigaray i krytyka męskiego podmiotu
}

\begin{abstract}
„Z całą pewnością odrzucenie, wykluczenie wyobraźni kobiecej, sytuuje kobietę tak, że doświadcza ona siebie jedynie fragmentarycznie, na słabo ustrukturowanych marginesach ideologii panującej, pośród wyrzutków i wygnańców, na marginesach lustra, ustawionego przez podmiot (męski) po to, żeby się sam odbijał, zdwajał"".
\end{abstract}

W ujęciu Irigaray, jednej z najciekawszych apologetek nowej różnicy, podmiot nowożytnej filozofii to androcentryczny konstrukt, w którym kobieta-przedmiot widziana jest oczami mężczyzny-podmiotu. Lustro nie odbija rzeczywistości, tylko zniekształca/tworzy świat, który chce odzwierciedlić. Światów jest więc tyle, ile luster.

Luce Irigaray pasjonują wszelkie różnice: zarówno między płciami, jak i poszczególnymi kobietami, a nawet te pojawiające się w obrębie pojedynczej kobiecej indywidualności. Toczy ona dyskusję na płaszczyźnie fi-

1 L. Irigaray, This sex which is not one, trans. C.Porter, C.Burke, New York 1985, s. 78 . 
lozoficznej, a jej główne zainteresowania ogniskują się wokół związku między rozumem i męskością. Badaczka uważa, że śledząc historię filozofii zawsze przychodzi zatrzymać się na obserwacji efektów uzurpacji męskiego rozumu. Nieobecność kobiet jest znacząca - Irigaray twierdzi, iż kobieta, a ściślej jej ciało, zostało odrzucone przez samoafirmację męskiego logosu.

Irigaray poddaje krytyce teorię Arystotelesa, w której biologiczna koncepcja kobiecej płci stanowi przypadek natury. Dowodzi to, według niej, ogromnej siły uprzedzenia oraz tego, że ucisk kobiet jest nie tylko materialny (tzn. istniejący w naocznej rzeczywistości), ale także symboliczny, mający swe źródła właśnie w filozofii i związanej z nią władzy². Jednak największą uwagę polemiczną skupia badaczka na konstrukcji podmiotu kartezjańskiego. Jej zdaniem pomiędzy podmiotem, a tym, co orzeka on o rzeczywistości, nie ma miejsca na indeterminacje. Innymi słowy, wszystko zależy od woli podmiotu, natomiast łącznik (copula) pomiędzy podmiotem a orzeczonym (najczęściej przedmiotem), jest znakiem tożsamości zarówno jednego, jak i drugiego. Kartezjański podmiot jest transcendentny; to, co jest transcendowane, to jego materialna podstawa, to zaś wyklucza ziemski przedmiot. Istnieje tylko „materia myślowa”, którą można definiować jako podmiot wyzbyty przedmiotowości, i która określa zawsze siebie w kategoriach „tu i teraz”, podając w wątpliwość wszystko, z wyłączeniem własnych procesów myślowych. Podmiot ten konstytuuje się poprzez wątpienie w swą wszechogarniającą mądrość, a także jest ostrożny w przyjęciu jakiegoś innego bytu do „swej świadomości”. Irigaray zauważa, że „materia myślowa” jest zawsze konstytuowana przez innego; tym innym według niej, jest ciało kobiety. Myślący męski podmiot żył i tworzył więc dzięki kobiecemu ciału, które zaspokajało jego popędy. Irigaray obala przeświadczenie o samowystarczalności podmiotu i jego samomyśleniu; uważa ona, że podmiot nie był w stanie myśleć sam, że jego myśl była zawsze odbita przez zwierciadło, jakim jest ciało kobiety. Więcej nawet, Irigaray pisze, że od pewnego czasu to ciało było odbiciem zupełnym. Przeczy to również samoistności podmiotu, który, aby być sam, musiałby się wyzbyć namiętności i chaosu. Dlatego ów podmiot mówiący - ,ja" jestem, więc ,ja" myślę, możemy wziąć w cu-

2 Koncepcje L. Irigaray wpisują się w kontekst debaty o przemocy symbolicznej, będącej tematem podjętym w pracach $\mathrm{M}$. Foucaulta, ale najpełniej sformułowanym przez P. Bourdieu. Zob.: tenże oraz L. J. D. Wacquant, Zaproszenie do socjologii refleksyjnej, przeł. A. Sawisz, Warszawa 2001. 
dzysłów, gdyż tak naprawdę to ,ja” nigdy do końca nie było prawdziwe konstytuowało je kobiece ciało.

Luce Irigaray, autorka Etyki różnicy seksualnej, uważa, że głównym zadaniem współczesności staje się przemyślenie i przepracowanie różnicy płci. W dobie męskich, fallocentrycznych i patriarchalnych pojęć, rysuje się ogromna potrzeba określenia kobiety i kobiecości, dokonana nie w opozycji czy odniesieniu do mężczyzny, ale niezależnie i - co ważne bez używania negatywnych określeń. Irigaray postuluje odnalezienie kobiecej specyfiki i autonomii, w tym także, a może przede wszystkim, kobiecego ciała i seksualności. Aby to osiagnąć potrzebne jest stworzenie swoistej kobiecej symboliki, języka, który pozwoli mówić kobiecie jej własnym głosem, wyrazi pragnienia, lęki, specyfikę wyobraźni. Chodzi głównie o to, żeby kobieta nie była skazana na wyłącznie męskie systemy symboliczne, które wyrażają to, co męskie, ale są niewystarczające albo nieadekwatne do pokazania kobiecego świata. Jeżeli tego świata nie można wyrazić, pokazać jego odmienności i tego, co własne, kobiecość zostaje skazana na milczenie. Niezwykle istotne jest również przemyślenie na nowo związku kobiety i mężczyzny, który byłby związkiem autonomicznych, różniących się podmiotów. Ta więź jest oczywiście więzią erotyczną, miłosną, która ma być twórcza i płodna nie tylko w znaczeniu dosłownym - przedłużenia gatunku biologicznego, ale również i w ten sposób, żeby dzięki związkowi ludzie odmiennych płci byli zdolni tworzyć siebie. Metoda Irigaray polega na odczytaniu na nowo i reinterpretacji dotychczasowej, patriarchalnej symboliki.

\section{Julia Kristeva i ,podmiot w kryzysie”}

Jak twierdzi Julia Kristeva, w każdym stuleciu kryzys przejawia się w innej postaci, ale można mówić przecież także o globalnym pojęciu kryzysu rozumianym jako przerwanie struktury, zakłócenie równowagi.

„Z tego punktu widzenia podstawowy kryzys, w którym trwa współczesny świat - a przez to szczególnie interesująca nas sztuka - zaczął ujawniać się w czasie Rewolucji Francuskiej, a jego skutki przeżywamy obecnie - kryzys, który był kryzysem władzy królewskiej, ale także kryzysem dyskusji w aspekcie komunikatywnym"3.

3 J. Kristeva, Obcość kulturowa i podmiot w kryzysie, wywiad S. Clark i K. Hulley, tłum. A. Mizińska-Kleczkowska, w: Podmiot w procesie, pod red. J. Jusiaka, J. Mizińskiej, Lublin 1999, s. 27. 
Poczucie, iż kultura współczesna znajduje się w stanie permanentnego i nie dającego się już zredukować kryzysu, przepełnia całą twórczość Kristevej, wyznaczając główne tropy w diagnozowaniu sytuacji jednostki w ogóle, w tym kobiety w szczególności:

„Zgodziłabym się z tymi historykami, którzy mówią, że dopiero obecnie dobiega końca Rewolucja Francuska. Widać to, kiedy weźmiemy pod uwagę problemy władzy, demokracji, religii oraz języka w powiązaniu z tożsamością seksualna. Sądzę więc, że rozpoczął się kryzys i nastapi cała seria kolejnych"4.

Zaczęła się więc epoka, w której żyjemy w kryzysie ciąłym. Podmiot kryzysu jest w swej najgłębszej istocie anarchiczny, co oznacza niemożność przewidywania dróg wyjścia ku stabilizacji. Z punktu widzenia kobiecej podmiotowości dążenie to nie wydaje się jednak wcale $\mathrm{z}$ definicji oczywiste.
„Anarchia ma na ogół negatywne konotacje. Jednak dla mnie, z per- spektywy permanentnego kryzysu anarchia jawi się jako nie thumiony stan subiektywności. Jest więc permanentnym stanem jej funkcjono- wania. W tym momencie pojawiają się dwie możliwości: albo ten kry- zys jest cierpieniem, patologia, albo może kreacją, odnową?"5

Tradycyjne pojmowanie modernizmu wiąże się z zespołem wyobrażeń, w którym uznanie wolnej woli podmiotu ponad formami dziedziczonymi jest błędną interpretacją tego, co przyniósł przez rozwój badań naukowych XX wiek. Wszystkie wielkie dzieła sztuki stanowić mają mistrzowską sublimację kryzysów subiektywności, które znane są w języku psychologii jako kryzysy psychotyczne. Poprzez dzieło i zabawę symbolami wyrażany jest kryzys subiektywności, który stanowi podstawę wszelkiej twórczości i który przyjmuje jako swój warunek konieczny możliwość przetrwania. Znaki tworzą ciało - jeżeli artysta nie będzie pracował, tworzył muzyki, pisał książek, stanie się człowiekiem chorym lub martwym. Moc symbolicznego tworzenia, która buduje somę (ciało) jest świetnie widoczna we współczesnych tekstach. Całe doświadczenie-literackie i krytyczne zajmuje się tym problemem.

Julia Kristeva w wielu swoich tekstach dokonuje procesualnej reinterpretacji podmiotu. Szczególnie przydatna jest wprowadzona przez nią w działaniach teoretycznoliterackich i poszerzona do opisu kultury i sytu-

4 Ibidem, s. 28.

5 Ibidem, s. 29. 
acji jednostki kategoria intertekstualności. Zrywa bowiem ona ze statycznym rozumieniem tekstu, skłaniając się ku ujmowaniu go jako „stawania się", a więc-procesu. Kristeva kwestionuje tożsamość tekstu i podmiotu, ale w przeciwieństwie do podmiotu kartezjańskiego czy ogłoszonej przez postmodernistów śmierci podmiotu, proponuje swoją własną koncepcję podmiotu w procesie. Innymi słowy, panującemu w zachodniej kulturze wzorowi podmiotu jednorodnego, niezmiennego, identycznego i tożsamego wobec samego siebie przeciwstawia ruchomy, dynamiczny, nietożsamościowy podmiot $\mathrm{w}$ procesie.

Intertekstualna lektura tekstu, która prowadzi do dostrzeżenia heterogeniczności i ambiwalencji tekstu, to pierwszy etap w próbie uchwycenia, czym jest podmiot $\mathrm{w}$ procesie.

„Inaczej niż w hermeneutyce, strukturalizmie czy semiologii mamy tu do czynienia nie tyle $z$ dążeniem do wykrycia jednego znaczenia, ile raczej z wielością semantyczną. [...] Proces interpretacji okazuje się tu nieskończony [...]. Intertekstualność to skrzyżowanie wypowiedzi dokonanych w innych tekstach, innych systemach znaków, to tekst mnogi, polifoniczny, zdynamizowany, mozaika. Mieści się tu echo, oddźwięk, aluzja, reminiscencja, nawiązanie do innych tekstów. To pierwszy krok Kristevej w nietożsamościowym traktowaniu nie tylko słowa, ale również doświadczenia, podmiotu, społeczeństwa. [...] Kristeva porównuje intertekst do drzewa, do czegoś pomiędzy jednością a wielością. Mnogi, lecz nie bezforemny korzeń, pień, gałęzie i liście to sieć powiązań, odwołań, aluzji, przetworzeń i odniesień międzytekstowych $[\ldots] "$...

Podmiot w procesie, kategoria zaproponowana przez Kristeva, jest trzecią drogą pomiędzy jednorodnym kartezjańskim cogito, zrównaniem podmiotowości, języka i rozumu a postmodernistyczną negacją podmiotu. Kristeva włącza się w tradycję postmodernistyczna, ale jednocześnie ją znacząco modyfikuje. $\mathrm{Z}$ postmodernistami koncepcję podmiotu w procesie łączy zacieranie granic między filozofią, historią filozofii, kultury i krytyki artystycznej; nieobecność teorii bytu, kierowanie się raczej ku filozofii języka niż ontologii; brak poszukiwania pewności; otwarta forma i płynność tekstu; przeświadczenie, że wszystko już było, że żyjemy w kulturze wyczerpania i pozostaje nam wyczerpywać historię kultury. To zaś, co proponuje Kristeva, a co różni ją od postmodernistów, to właśnie

6 T. Kitliński, Podmiot w procesie wedtug Julii Kristevej, w: Podmiot w procesie ..., op. cit., s. 50 . 
wyeksponowanie problemu podmiotowości i próba, choć wysoce niesystematyczna, zbudowania całościowej teorii podmiotu i intersubiektywności; ponadto badaczka nie lekceważy natury, zajmuje się raczej rekonstrukcją niż dekonstrukcją historii kultury, interesuje ją również interpretacja dyskursu religijnego.

Kiełkowanie sensu, znaczenie rodzące się; sens istnieje, ale konstytuuje się w sposób mnogi i nieskończony; należałoby zatem mówić o sensach, a nie sensie. Koncepcja Kristevej mieści się między oczywistością i ścisłością znaczenia, a jego całkowitym brakiem.

„Podmiot w ujęciu Kristevej znajduje się w procesie współdziałania dwu stref: semiotyczności i symboliczności, splata się w nich ciało i dusza (chiazm). Podmiot nie równa się zatem świadomości, jest bogatszy niż ego cogito" 7 .

„Podmiot w procesie to obfitość, przelewanie się tekstów w ich różnorodności, barok znaków i ich krzyżowań. Jest pełen napięć, niedomknięty, czasuje się, zmienia - stajemy się nieustannie nowi. Można określić podmiot w procesie jako metamorficzny i pletoryczny. Niegotowy, in statu nascendi podmiot nieustannie się upodmiotawia, niedokończony-niedokańczalny. Podmiot $\mathrm{w}$ procesie to homo loquens, którego język to również proces" ${ }^{\text {" }}$.

\section{Donna Haraway i cyborg}

Ciekawą koncepcją podmiotowości związaną z postmodernistyczną śmiercią człowieka lub kryzysem egzystencjalnie rozumianego podmiotu jest propozycja amerykańskiej badaczki, Donny Haraway ${ }^{9}$. Przedstawia ona cyborga, a właściwie cybernetyczny organizm, który jest czymś w rodzaju hybrydy składającej się z maszyny i żywego organizmu; swoiste pomieszanie fikcji i rzeczywistości.

Haraway odwołuje się do skonstruowanego przez różnorodne ruchy feministyczne lub krytykę feministyczną modelu doświadczenia kobiecego, które tak jak cyborga trudno zdefiniować, ponieważ należy do dwóch porządków; łączy w sobie zarówno fikcję, jak i rzeczywistość, jest jednym

7 Ibidem, s. 56.

8 Ibidem, s. 58.

9 D. Haraway, A Manifesto for Cyborgs: Science, Technology, and Socialist Feminism in the 1980s, w: Feminism/Postmodernism, ed. and with an Introduction by Linda J. Nicholson, New York-London 1990, s. 190-233. 
i drugim. Nie jest to jednak zwyczajne, pokojowe współistnienie czy wyłanianie się jednego z drugiego, ale raczej walka na śmierć i życie - do końca nie wiadomo, gdzie się zaczyna człowiek, a kończy maszyna lub odwrotnie. Badaczka zwraca uwagę, że chociaż połączenie człowieka z maszyną nie jest czymś zupełnie nowym, to we współczesnej medycynie ludzkie ciało, jak nigdy dotąd, nieustannie penetrowane jest przez mniej lub bardziej skomplikowane maszyny. Podobnie rzecz się ma z wojną; ta nowoczesna konfrontacja to przecież walka między maszynami (komputerami), a nie ludźmi w bezpośredniej styczności na polu walki. Zatem teza postawiona przez Haraway wygląda następująco: wszyscy jesteśmy cyborgami, a podmiot egzystencjalny (człowiek) jest nierozerwalnie powiązany $\mathrm{z}$ maszynami i uzależniony od nich.

W interpretacji badaczki amerykańskiej nie jest to jednak tragedia człowieczeństwa. Wprawdzie w tradycji kapitalizmu związek między maszyną i człowiekiem to nieustanna wojna (ujarzmianie natury, czynienie sobie ziemi poddana, dokonywane jest siłą technologii), jednak celem nowej kultury i feminizmu jest nie tyle zrezygnowanie z maszyn czy walka z nimi, ale raczej udowodnienie, że istnieje nieodkryta jeszcze do końca przyjemność w zacieraniu granic między człowiekiem i maszyną. Chodzi także o przypomnienie odpowiedzialności za kształtowanie rzeczywistości, ale w dalszej konsekwencji - za utrzymanie możliwej do uchwycenia różnicy między rzeczywistością (np. ludzie umierający na wojnie) a jej przedstawieniem (śmierć oglądana na symulatorze lotu albo na monitorze samolotu bojowego). Świat cyborgów pozbawionych rodzaju, poza niekwestionowanym powiązaniem z postmodernizmem (symulacrum) ma również tę cechę, że do wcielenia cyborga nie odnosi się historia zbawienia. Ponieważ nie ma problemu z kompleksem Edypa, istnieje szansa na uleczenie seksistowskich chorób. Cyborg jest także postgenderowy - nie ma płci i nie odnoszą się do niego takie kategorie jak biseksualność czy androgynizm, bo nieobecny jest charakterystyczny dla kultury zachodniej mit założycielski, mówiący o pierwotnej jedności i oddzieleniu. Cyborg stoi poza mitem. $Z$ definicji nie jest niewinny, w sobie samym oddaje upadek podziału na publiczne i prywatne. Nie powstał z prochu i nie marzy o obróceniu się w pył, a w odróżnieniu od Frankensteina - nie oczekuje zbawienia.

Haraway wskazuje również na trzy kluczowe załamania obszarów granicznych, które konstytuowały dotąd podmiot antropologiczny. Po pierwsze, granica człowiek - zwierzę przestała być oczywista. Badania prowadzone na małpach, a zwłaszcza szympansach, pokazują, że to, co 
wydaje się podstawowe dla odróżnienia człowieka od zwierzęcia, jest kolejno kwestionowane i upada. Co więcej, ludzie przestają w ogóle potrzebować takiego rozróżnienia! Do głosu dochodzi tendencja wręcz odwrotna, domagająca się traktowania praw ludzi i zwierząt $\mathrm{w}$ taki sam sposób. Cyborg, pojawiający się w momencie załamania granicy między światem ludzi i zwierząt, ucieleśnia ideę połączenia (także i tych) dwóch światów.

Po drugie, zostaje przekroczona różnica między żywym organizmem i maszyną. Do tej pory tylko człowiek był konstruktorem, a więc kreatorem maszyn. Rozwój techniki poszedł jednak tak daleko, że wymyślona kiedyś przez człowieka maszyna dzisiaj sama projektuje inne maszyny, np. układy scalone, a w przyszłości może dojść do tego, że projektować będzie także i żyjących. Jak mówi Haraway, „nasze maszyny są niepokojąco żywe, a my sami zastraszająco nieruchomi"10.

Po trzecie, uległa zatarciu i jest dzisiaj niejasna granica między tym, co fizyczne i nie. Miniaturyzacja zmieniła doświadczenie mechanizmu - sto lat temu mechanizm był duży i namacalny, dzisiaj zaś maszyny są mikroelementami, znajdują się wszędzie i czasem są wręcz niewidzialne (mają bardzo małe rozmiary albo też ich elementami konstrukcyjnymi są światło i fale). Dziś to ludzie są materialni, nieprzezroczyści, ciężcy. Cierpienie człowieka, który zbyt jest związany z ziemią, by mógł wzbić się w chmury, w kulturze techno istnieje nadal, tyle że zmieniło się jego źródło - teraz to nie duchy i anioły przypominają mu o jego ułomności, ale jego własne maszyny.

Ponieważ załamały, czy załamują się, obszary graniczne współczesnego świata, również feminizm przestał być oczywisty i wymaga nieustających dookreśleń. Ci, którzy chcieliby obronić jedność feminizmu, sami są podzieleni, sami się nawzajem wyłączają przez nazywanie i klasyfikowanie. Poczucie jedności kobiecego podmiotu, bycia kobietą jest wypierane przez doświadczenie klasy, orientacji seksualnej i koloru skóry. Podmiot ponownie zostaje więc pokawałkowany według kategorii patriarchalnego świata, a pojęcie kobiety samej, jej podmiotowość, zaczyna się wymykać. Kobieta nie jest już niewinna, bo sama wobec innych kobiet stosuje metody alienujące. Opis świata kobiet jest wplątany w system informatyczno-gospodarczy ogarniający cały glob. Kobieta jest przez ten system wykorzystywana, bo takie społeczne wyznaczniki jak: dom, praca,

10 Ibidem, s. 194. 
ciało ulegają swoistemu zatarciu, czego konsekwencjąjest kłopot w rozumieniu samej siebie. Problemu nie można rozwiązać generalnie, każdy podmiot musi to zrobić indywidualnie, sam dla siebie.

W obliczu rosnącej fragmentacji świata, Haraway proponuje zamiast kobiecego podmiotu wprowadzenie pokrewieństwa z wyboru. Tym „krewnym" może być podmiotowość cyborga, która to podmiotowość, jak i sam cyborg zbudowane są z fragmentów. Elementy są rozkładane i mogą być dowolnie wymieniane, dlatego podział dychotomiczny zostaje zakwestionowany. Każdy, w tym i podmiot kobiecy, może dowolnie się kształtować, wymieniać i przestawiać budujące go elementy, w zależności od potrzeb otaczającego świata. $Z$ drugiej strony nasz świat coraz bardziej zależy od elektroniki, a mikroelektronika jest techniczną podstawą postmodernistycznego świata symulakrów.

\section{Summary}

Post-modernist debate focuses around the concept of the world and man presented by the philosophy described as the Enlightenment, Modernist or modern philosophy. At its culmination is the paradigm of knowledge developed by Kant and Descartes. The feminist theory of emancipation could not ignore the transformation reflected in every realm of cultural reality. The belief in a monolithic subject free from limitations has collapsed, as a result of events over the past few centuries and has left only the melancholy of uprooting. Feminism, particularly its second wave, has also joined the dispute on the shape of a new subjectivity. This discourse offers more than just a different outlook upon man, but also the reflection that points out to all the difficulties related to the discussion of the subject. 